\title{
O texto publicitário como suporte pedagógico para a construção de um sujeito crítico'
}

\section{Tânia Márcia Cezar Hoff}

Professora do Programa de Mestrado em Comunicação

e Práticas de Consumo da ESPM.

E-mail: thoff@espm.br

Os meios de comunicação de massa podem ser considerados uma das nossas principais fontes de informação. Convivemos com tanta familiaridade com as idéias e imagens neles veiculadas que as aceitamos como verdade e as utilizamos para guiar nossas decisões e escolhas na vida. Como atinge um contingente numeroso e variado de pessoas, a mídia tende a ser uma fonte hegemônica e homogeneizadora de informação. Daí ser considerada uma espécie de opinião pública: o que divulga e como divulga torna-se conhecido e aceito por grande parte de sua audiência.

A mídia seleciona, organiza e propaga as informações: o que ela apresenta a respeito dos muitos temas e/ou fatos que aborda não é verdade absoluta, é apenas uma leitura possível, um dos muitos aspectos de um mesmo tema e/ou fato. As leituras por ela divulgadas são fragmentos ou recortes do mundo: não temos acesso à totalidade dos acontecimentos por meio da mídia:

O mundo que nos é trazido, que conhecemos e a partir do qual refletimos é um mundo que nos chega editado, ou seja, ele é redesenhado num trajeto que passa por centenas, às vezes milhares, de filtros até que "apareça" no rádio, na televisão e no jornal. Ou na fala do vizinho, nas conversas dos alunos... São esses filtros - instituições e pessoas - que selecionam o que vamos ouvir, ver ou ler; que fazem a montagem do mundo que conhecemos ${ }^{2}$.

O fato de os meios de comunicação veicularem um número elevado de informações, ampliando as possibilidades de acesso e de propagação da informação, não garante a produção de conhecimento, pois há uma diferença entre consumo de informação e construção de conhecimento. Ou seja, a mídia divulga informação e não conhecimento.

1. Este artigo foi apresentado no Núcleo de Pesquisa - Comunicação Educativa, no XXVIII Congresso Brasileiro de Ciências da Comunicação da Intercom, realizado em setembro de 2005.

2. BACCEGA, M. Aparecida. Dez anos a serviço da construção do campo comunicação/educação. Comunicação e Educação. São Paulo: CCA/ ECA/USP/Paulinas, ano X, n. 1, p. 264, jan./abr. 2005. 
A mera assimilação de informação não nos modifica, não nos transforma nem sempre nos liberta para a reflexão e a ação. Ter acesso à informação é o primeiro passo para a construção do conhecimento, que implica a realização de operações mentais como a comparação, a análise, a hierarquização etc., de modo que seja possível estabelecer relações entre as muitas informações e chegar a sínteses ou, em outros termos, a opiniões, reflexões e tomadas de decisão.

$\mathrm{O}$ conhecimento pressupõe consciência - uso das potencialidades mentais para além da memorização e do mero registro de informação. O acesso e a assimilação de informações possibilitam apenas acúmulo ou soma de dados. Eis por que conhecer: quanto maior o conhecimento, maior a capacidade de estabelecer relações e de agir de modo a interferir na realidade, quer externa, quer internamente - no plano psicológico.

Por exemplo: uma pessoa extremamente informada e, ao mesmo tempo, incapaz de agir e de interferir na realidade que a cerca encontra-se no nível de mero acúmulo de informação, sem produção de conhecimento, o que a inviabiliza de tomar decisões significativas para colocar a vida em movimento - ação modificadora da realidade. Ou seja, tal condição a impossibilita de atuar como cidadã.

No mundo contemporâneo, que se caracteriza pela divulgação e circulação de informações, o saber impõe-se como uma necessidade, posto ser uma das principais - talvez a única - vias de desvendamento do mundo. Saber ou conhecer algo implica seu controle: classificar, tipificar e dissecar o objeto, de modo que seja possível organizá-lo, isto é, compreender sua natureza e dominar suas manifestações. Saber que algo existe e ter conhecimento a seu respeito nos revela o grau de dominação ao qual estamos submetidos. É, pois, o saber que nos alça à condição de cidadãos.

Se a construção de conhecimento implica reflexão e "o espaço privilegiado para a reflexão é sempre, e continuará sendo, a escola”, entendemos que o processo ensino/aprendizagem deva buscar a humanização, ou seja, a construção de um sujeito humanizado, consciente de si e do mundo que o cerca ${ }^{4}$. Na Lei n. 9.394, de Diretrizes e Bases da Educação, seção IV ${ }^{5}$, encontra-se expresso semelhante objetivo da escola: desenvolver habilidades e capacidades que possibilitem ao educando pensar e interpretar o mundo.

No que se refere à cidadania, destaquemos, dentre outras, duas finalidades do Ensino Médio apontadas na referida lei:

I - a preparação básica para o trabalho e a cidadania do educando, para BACCEGA, op. cit. p. 9.

4. FREIRE, Paulo. Pedagogia do oprimido. Rio de Janeiro: Paz e Terra, 1983.

5. Disponível em: <http:// portal.mec.gov.br>. Acesso em: 6 jun. 2005 
do discurso publicitário como suporte pedagógico no Ensino Médio público, por exemplo, pode auxiliar a escola na construção de cidadãos críticos, pois é preciso mais que consumir informações; é necessário processá-las para tomar decisões e agir, entendendo as implicações de uma decisão e/ou ação. Ou, ainda, conforme Ernani Fiori que, ao prefaciar Pedagogia do oprimido, de Paulo Freire, afirma ser o ensino/aprendizagem um processo de construção do cidadão, que desenvolverá condições para "dizer a sua palavra, pois, com ela, constitui a si mesmo e a comunhão humana em que se constitui; instaura o mundo em que se humaniza, humanizando-o"

Focamos nossa discussão no Ensino Médio de escolas públicas por se tratar da etapa final da educação básica e último momento de formação geral. Os Parâmetros Curriculares Nacionais para o Ensino Médio (PCNEM), elaborado para orientar professores na busca de novas abordagens e metodologias de ensino, propõem:

[...] a formação geral, em oposição à formação específica, o desenvolvimento da capacidade de pesquisar, buscar informações, analisá-las e selecioná-las; a capacidade de aprender, criar, formular ao invés de simples exercício de memorização 7 .

Ressalte-se ainda que, segundo Luzio e Araújo, as pesquisas realizadas pelo Sistema Nacional de Avaliação da Educação Básica (SAEB), entre 1995 e 2001, revelam que a média nacional de desempenho em língua portuguesa caiu $10 \%$ em todo o período:

Os dados mais recentes indicam que $42 \%$ dos alunos do $3^{\circ}$ ano do Ensino Médio estão nos estágios "muito crítico" e "crítico" de desenvolvimento de habilidades e competências em Língua Portuguesa. São estudantes com dificuldades em leitura e interpretação de textos de gêneros variados. Não são leitores competentes e estão muito aquém do esperado para o final do Ensino Médio. Os denominados "adequados" somam apenas $5 \%^{8}$.

A julgar por esses dados, há uma distância considerável entre os objetivos propostos na Lei de Diretrizes e Bases da Educação e nos Parâmetros Curriculares Nacionais para o Ensino e a efetiva formação que as escolas promovem.

A avaliação de desempenho dos educandos revela que a escola não atinge os objetivos propostos na lei. Diante desse quadro, o texto publicitário mostra-se como possibilidade de aproximação entre escola e vida cotidiana: embora problemas de natureza variada concorram para as dificuldades de se obterem indicadores satisfatórios de desempenho dos educandos no ensino formal, parece-nos que um dos aspectos fundamentais para a reversão da atual situação do ensino no Brasil seja promover um processo educacional a partir do repertório/ experiência do educando - conforme propõe o método Paulo Freire ${ }^{9}$. Dentre outros caminhos possíveis, talvez o texto publicitário possa auxiliar professores e educadores nessa tarefa, posto que está inserido no cotidiano do educando, servindo-lhe de referência para as práticas de interação social e afetando-lhe os processos de subjetivação.
6. FIORI, Ernani. Aprender a dizer a sua palavra. In: FREIRE, Paulo. Pedagogia do oprimido. Rio de Janeiro: Paz e Terra, 1983. p. 7.

7. Disponível em: <http:// portal.mec.gov.br>. Acesso em: 6 jun. 2005.

8. LUZIO, Nildo; ARAÚJO, Carlos Henrique. O desafio do ensino médio. Disponível em: <http:// www.inep.gov.br/imprensa/artigos/o_desafio_ensino_medio.htm >. Acesso em: 17 mar. de 2007.

9. Ver as seguintes obras de Paulo Freire: (1) Pedagogia do oprimido. Rio de Janeiro: Paz e Terra, 1983; (2) Pedagogia da autonomia: saberes necessários à prática educativa. São Paulo: Paz e Terra, 1995. (3) A importância do ato de ler em três artigos que se completam. São Paulo: Cortez, 1995. 
A utilização do texto publicitário como suporte pedagógico estabeleceria uma ponte entre o saber formal e a experiência vivida: material de fácil acesso para professores e educandos e que tem a vantagem de estar ao alcance de todos. Um filme requer infra-estrutura tecnológica para ser visto; da mesma forma, uma fita cassete ou um CD-ROM. Por sua vez, o texto publicitário - especialmente aquele veiculado na mídia impressa - pode passar de mão em mão e também ser transcrito no quadro-negro, fato relevante para uma escola com carências estruturais e materiais como a brasileira.

\section{O TEXTO PUBLICITÁRIO NA SALA DE AULA}

Atualmente, escola e mídia são experiências de todos, pois toda a população - ou grande parte dela - passa pela escola e é submetida à difusão da mídia. Nesse contexto, trazer para a sala de aula, como objeto de estudo e reflexão, um tipo de texto que já se encontra inserido na vida dos educandos significa atuar no sentido de uma educação para a mídia, ou seja, da escolarização de um saber ainda não institucionalizado.

Len Masterman aponta algumas razões que justificam a necessidade de se abordar a mídia nos projetos pedagógicos como conteúdo das disciplinas:

[...] o consumo elevado das mídias [...]; a importância ideológica das mídias, notadamente a publicidade; o aparecimento de uma gestão da informação nas empresas [...]; a penetração crescente das mídias nos processos democráticos [...]; a importância crescente da comunicação visual e da informação em todos os campos [...]; a expectativa dos jovens de ser formados para compreender sua época $[. .$.$] ; o crescimento nacional e internacional das privatizações de todas as$ tecnologias ${ }^{10}$.

Note-se uma nítida relação entre educação e cidadania. Estudar os meios de comunicação significa atualizar a escola, visando favorecer a tomada de consciência de que todos nós somos alvos da mídia. Parece consenso que o primeiro argumento de defesa para esta educação reside na constatação do lugar das mídias na vida cotidiana. No entanto, trazer o texto publicitário para a sala de aula implica considerar dois perigos ${ }^{11}$ : de um lado a adesão acrítica à tecnologia e, de outro, o repúdio apocalíptico aos efeitos alienantes da mídia.

A adesão acrítica à tecnologia desloca o problema para outra esfera que

10. MASTERMAN, Len, apud GONNET, Jacques. Educação e mídias. São Paulo: Loyola, 2004. p. 24.

11. CITELLI, Adilson. Escola e os meios de comunicação. In: CHIAPPINI, Lígia (Coord.). Aprender e ensinar com textos não escolares. São Paulo: Cortez, 2002. p. 17-18. não a humana, sugerindo que os desenvolvimentos científico e tecnológico são suficientes para resolver questões de democracia e cidadania por possibilitarem o acesso à informação.

No repúdio apocalíptico reside um temor aos efeitos nocivos da mídia que afeta tanto o jovem despreparado quanto a escola com sua missão quase impossível de salvá-lo. Eis aqui dois preconceitos fortemente enraizados no imaginário escolar: o primeiro consiste na idéia de que o jovem encontra-se em perigo, indefeso e despreparado diante da mídia insidiosa que tudo pode. E o segundo refere-se à função crítica da escola que se responsabiliza pela denúncia dos malefícios 
promovidos pela mídia. Tal denúncia, no entanto, deve ser formalizada em projetos pedagógicos que analisem as características do discurso midiático e seu impacto sociocultural. Trazer a mídia, mais especificamente o texto publicitário, para a sala de aula requer algo mais que o repúdio, o medo e a negação da mídia. É dever da escola preparar o educando para ser leitor crítico das mensagens midiáticas, posto que elas já fazem parte do seu cotidiano.

Ainda no que se refere ao repúdio à mídia, o texto publicitário é particularmente criticado por ser persuasivo e argumentativo; não é neutro. Entretanto, não há texto neutro! O livro didático poderia ser acusado de crime semelhante. Ambos - a publicidade e o livro didático - apresentam estereótipos, ideologias e valores que podem afetar a compreensão de mundo dos educandos. O problema não está no conteúdo dos textos ou nas características de cada discurso, mas na condução do processo ensino/aprendizagem. O texto publicitário, enquanto material didático, abre perspectivas para a sistematização de procedimentos de análise em diferentes disciplinas, de modo que o educando possa distanciar-se da recepção descompromissada e arregimentar elementos para uma leitura crítica.

Critica-se negativamente a mídia também por se considerar que ela produza um rebaixamento do saber ${ }^{12}$. Desvela-se aqui uma hierarquia: o saber elevado, associado ao conhecimento livresco, e o baixo, ao audiovisual e ao multimídia. Talvez exista uma percepção geral, um imaginário social, a fundamentar o medo que se tem das mídias: "A história mostra oposições resolutas quando aparece uma nova técnica que subverte as aposições dos depositários do antigo saber"13. A escrita foi considerada uma ameaça à oralidade, ou seja, uma nova tecnologia capaz de deteriorar o saber instituído. Hoje, entretanto, o livro é um depositário do antigo saber e encontra-se ameaçado pela televisão, pela internet etc.

Avaliado de modo preconceituoso, o texto publicitário - que é mensagem midiática - é considerado um saber rebaixado, diferentemente da literatura, por exemplo, que tem status de saber elevado. Diante das dificuldades do educando em decodificar textos, a mensagem publicitária - que não deve ser entendida como saber menor - poderia constituir um material facilitador na preparação do leitor competente, condição almejada para o egresso do Ensino Médio.

Aprender e ensinar com textos não escolares ${ }^{14}$, obra que apresenta as primeiras conclusões da pesquisa denominada "A circulação dos textos na escola", realizada em quatorze escolas do ensino público - redes estadual e municipal - e em uma particular da cidade de São Paulo, constata que raramente a mídia encontrase inserida como objeto de estudo nos projetos das disciplinas desenvolvidas; ou seja, embora presente na vida dos educandos, encontra-se fora da escola. A mesma pesquisa também identifica a existência de um discurso subterrâneo, ou seja, os educandos "vivem uma intensa relação com as linguagens e os conhecimentos não-sistematizados pelo discurso didático-pedagógico"15.

No sistema educacional brasileiro, ainda não se notam ações de uma educação para a mídia, traduzida em disciplinas ou em tópicos de conteúdos programáticos. Ainda que existam iniciativas de algumas instituições e
12. Ver POPPER, Karl. Televisão, um perigo para a democracia. São Paulo: Gradiva, 1995.

13. GONNET, op. cit., p. 33. 14. CHIAPPINI, op. cit., p. 7. 15. CITELLI, op. cit., p. 19. 
comunicação \& educação • Ano XII • Número 2 • maio/ago 2007

também de professores pesquisadores e/ou interessados em trazer para a escola a experiência dos educandos com a mídia, elas limitam-se à prática isolada. De modo geral, a escola parece viver um descompasso entre o estrito discurso didático pedagógico e o midiático: o primeiro formaliza "as ações na sala de aula, constituindo a natureza 'única e diferenciada' do discurso escolar" ${ }^{\prime \prime}$; e o segundo, as ações para o entretenimento e o prazer, "pressionando de fora, existindo na fala dos alunos [...], circulando de forma subterrânea"17.

Caso se considere que as mensagens midiáticas não são neutras - aliás, as mídias também não o são - e que apresentam maneiras de perceber e de compreender o mundo, devemos revisar a opinião segundo a qual a única função da mídia é informar ou divertir. Nessa perspectiva, a mídia como fenômeno geral e as mensagens dos diferentes meios podem constituir objeto de estudo previsto nos projetos pedagógicos.

Duas características do texto publicitário sugerem sua utilização como suporte pedagógico: em primeiro lugar, o caráter de crônica social; e, em segundo, a sintonia com a visão de mundo dos mais diversos grupos da sociedade.

A publicidade pode ser considerada uma espécie de crônica social quando estabelece um diálogo entre os acontecimentos do presente e as tendências de comportamento, expectativas, desejos e percepções do público. É possível pensar o discurso publicitário como um tradutor da concepção econômico-mercadológica da sociedade.

Sintonizado com a visão de mundo dos grupos sociais aos quais se destina, esse tipo de texto extrapola a finalidade comercial: é produção cultural na medida em que interpenetra todas as instâncias da vida em sociedade. Uma campanha publicitária - ou mesmo uma peça publicitária isolada - é construída a partir dos valores dos grupos sociais aos quais se destina.

Devido a sua natureza massiva, a publicidade alcança todos os rincões do Brasil. Até mesmo onde a escola ainda não chegou, a publicidade - cartazes, folhetos, anúncios etc. - já o fez. Parece razoável considerar sua função colonizadora nas localidades muito carentes e/ou distantes, nas quais as instituições representativas do poder político - como a escola - raramente se instalam.

O lugar do texto publicitário na cultura parece não suscitar dúvidas; no entanto, sua finalidade comercial e natureza persuasiva parecem desqualificálo para funções pedagógicas. As acusações mais comuns à mídia, conforme discorremos, estão atreladas às críticas ao discurso publicitário que, segundo seus detratores, seduz para dominar e para estimular o consumo.

À parte o temor e o preconceito, o texto publicitário encontra-se disponível para emergir nas salas de aula e, como material pedagógico, possibilitar que o educando, partindo de sua experiência de vida, desenvolva competência de leitura do mundo para falar a sua palavra e fazer a sua ação. Ou ainda, conforme Paulo Freire, para humanizar-se.

É fato que a atual situação do sistema educacional brasileiro é grave e

16. Ibid., p. 21

17. Ibid. complexa, e para enfrentá-la são necessárias medidas articuladas em âmbito nacional. Infelizmente, discutir educação, para as mídias, ainda significa deba- 
ter ações isoladas. Daí considerarmos que elas carecem de auxílio e incentivo: pode-se fomentar as discussões a respeito da mídia e ampliar seu uso efetivo em sala de aula. Acreditamos que as possibilidades de utilização do texto publicitário como suporte pedagógico são ricas e podem consistirem um primeiro passo para que o ensino das mídias faça parte das práticas pedagógicas em nosso país.

\section{DIALOGISMO E CONSTRUÇÃO DE CONHECIMENTO}

Os estudos de Bakhtin sobre a linguagem desenvolveram-se a partir do conceito de dialogismo - princípio constitutivo da linguagem e do discurso. Para ele, o discurso se constrói a partir de muitas vozes, isto é, a partir do outro/auteridade, posto que "nenhuma palavra é nossa, mas traz em si a perspectiva de outra $\mathrm{voz}{ }^{18}$. Concebendo dialogismo como "o espaço interacional entre o eu e o tu ou entre o eu e o outro, no texto"19, Bakhtin entende linguagem como algo que se constitui no e a partir do social.

O texto publicitário comporta muitas vozes: estudá-lo sob tal pressuposto teórico pode auxiliar o professor a construir um procedimento de leitura capaz de possibilitar ao educando reconhecer suas características preponderantes e também as formas argumentativas e persuasivas que imperam nas mensagens comerciais. Distanciando-se do papel de consumidor do discurso publicitário, ele poderá compreender a relação entre cidadania e consumo.

Uma das formas de construção de conhecimento que o Ensino Médio público deve fomentar, criando competências e estabelecendo vínculos com o mundo fora do ambiente educacional, parece exeqüível mediante uma preparação para a leitura do texto publicitário, visando à leitura do mundo. Eis um dos primeiros passos para a humanização, isto é, para a conscientização do educando: uma vez sujeito na leitura do texto publicitário, acreditamos que ele possa formar-se enquanto sujeito na leitura do mundo.

Em seu Marxismo e filosofia da linguagem, no capítulo intitulado "O discurso de outrem", o autor russo comenta o aspecto dialógico ou polifônico da linguagem: "[...] a unidade real da língua que é realizada na fala (Sprache als Rede) não é a enunciação monológica individual e isolada, mas a interação de pelo menos duas enunciações, isto é, o diálogo".

A enunciação, isto é, o texto é resultado de muitas vozes que constituem o emissor e o receptor. Antes de a teoria da recepção trazer à luz o papel ativo do receptor na leitura do texto/no processo de decodificação, o conceito de discurso dialógico ou polifônico, proposto por Bakhtin, pressupunha a interação entre emissor e receptor no contexto social, pois nenhuma atividade lingüística pode realizar-se fora das relações sociais.

A rede social e o tecido discursivo são dinâmicos e se alimentam mutuamente: não existe uma fala pura, isto é, única, original, sem influência de
18. BARROS, Diana; FIORIN, José (Orgs.). Dialogismo, polifonia, intertextualidade. São Paulo: EDUSP, 1994. p. 3.

19. Ibid. 
comunicação \& educação • Ano XII • Número 2 • maio/ago 2007

outras. O enunciado é sempre plural, resultado de outros, também fruto da interação discursiva.

[...] aquele que apreende a enunciação de outrem não é um ser mudo, privado da palavra, mas, ao contrário, um ser cheio de palavras interiores. Toda a sua atividade mental, o que se pode chamar o "fundo perceptivo", é mediatizado para ele pelo discurso interior e é por aí que se opera a junção com o discurso apreendido no exterior. A palavra vai à palavra ${ }^{20}$.

Considerada a partir de uma dimensão social, a linguagem pressupõe interação e também troca; nesse sentido, a manifestação individual é resultado do discurso de muitos eus. Daí o conceito de dialogismo, das muitas vozes que se instauram num discurso: "[...] os indivíduos não recebem a língua pronta; em vez disso, ingressam numa corrente móvel de comunicação verbal. As pessoas não 'aceitam' uma língua; em vez disso, é através da linguagem que elas se tornam conscientes e começam a agir sobre o mundo, com e contra os outros" ${ }^{21}$.

Para Bakhtin, "a vida começa apenas no momento em que uma enunciação encontra outra, ou seja, quando começa a interação verbal, mesmo que não seja direta, 'de pessoa para pessoa', mas mediatizada pela literatura"22; e acrescente-se, aqui, pelos meios de comunicação de massa. O discurso publicitário enseja, pois, a possibilidade de se estudar o dialogismo ou a polifonia, em especial as relações interdiscursivas nele existentes. Nesse sentido, a escola deve operar como um espaço de confluência de muitos discursos, entre eles, o publicitário.

A língua e a vida encontram-se no mesmo plano; não existe uma linha divisória que as separe: "A língua penetra na vida através dos enunciados concretos que a realizam e é também através dos enunciados concretos que a vida penetra a língua"23. O conceito bakhtiniano possibilitaria ao educando distanciar-se do texto publicitário para compreender as várias instâncias de poder que ali se articulam.

Se língua e vida estão em consonância, escola e vida também deveriam estar. Consideremos tais aspectos no estudo do texto publicitário que, para atingir de forma eficiente um receptor/coletivo com um número definido de inserções, acompanha as modificações de uso de uma determinada língua em tempo real, isto é, segue as transformações conforme elas vão se disseminando entre seus usuários/falantes e registra as formações discursivas de diferentes grupos dentro da sociedade, dada a necessidade de atualização imposta pelos imperativos de mercado. Por meio do discurso publicitário, a palavra vai à palavra: reconhecendo os mecanismos de construção do texto, o educando estará mais próximo de perceber as relações de poder na sociedade contemporânea.

Se a competência lingüística prevê a compreensão das idéias explícitas e, também, das implícitas num enunciado, trabalhar com a noção de que o texto comporta muitos discursos - muitas visões de mundo - que concorrem numa sociedade, a nosso ver, auxiliaria o educando do Ensino Médio a compreender-se como cidadão ao perceber as articulações que o texto publicitário e a 
sociedade engendram. Em artigo que apresenta considerações na mesma direção de nossas reflexões, Clóvis de Barros Filho ${ }^{24}$ comenta os resultados da pesquisa realizada com educandos de Ensino Médio acerca das percepções sobre uma peça publicitária do refrigerante Sukita, apontando que o entendimento deles se alterou após uma discussão com intervenção.

\section{DESAFIOS PARA O PROFESSOR E PARA O EDUCANDO}

Educar para as mídias ou utilizar o texto publicitário como suporte pedagógico não é panacéia para resolver os problemas que o sistema educacional brasileiro enfrenta. Mas, certamente, lembrando os objetivos do método Paulo Freire, tais práticas pedagógicas podem auxiliar na construção do conhecimento e na formação de um educando capaz de posicionar-se criticamente diante das mensagens publicitárias, reconhecendo que elas não são neutras, já que marcadas por uma gama de interesses e atravessadas por diversas vozes.

Ignorar o impacto da mídia no comportamento das pessoas, tanto no meio urbano quanto no rural, significa preterir o atual momento da sociedade brasileira. Entretanto, a escola pode desempenhar sua função: estudar as mídias para promover o desenvolvimento de educandos conscientes de seu lugar na sociedade e de seu papel como cidadãos. Se o texto publicitário é rico em mecanismos de persuasão e argumentação, pode a escola utilizar-se de tal riqueza para engendrar nos educandos a reflexão e o pensamento crítico.

Educar para as mídias requer que os professores e demais responsáveis pelo Ensino Médio considerem as mensagens midiáticas e suas linguagens como item a ser estudado e inserido no planejamento pedagógico. Demanda ainda muito cuidado na condução das atividades de ensino/aprendizagem: a adesão acrítica e o repúdio apocalíptico - atitudes comuns em relação às mídias, conforme mencionamos no desenvolvimento do texto - devem ser evitados, de modo que o professor seja o organizador de um procedimento metodológico para a análise das mídias; seja o coordenador do processo de aquisição de conhecimentos do educando. Em suma, que o professor promova condições de desvelamento do objeto para os educandos, tomando como guia os objetivos definidos no planejamento da disciplina.

Trazer para a sala de aula o que está presente no cotidiano dos educandos, embora pareça algo fácil, consiste em um desafio para ambas as partes envolvidas no processo ensino/aprendizagem. O educando terá de abandonar um entendimento prévio e sedimentado pela prática para assumir novos conhecimentos que, certamente, apresentarão diferentes entendimentos da mídia e, em especial, do discurso publicitário. Por sua vez, o professor terá de despir-se de preconceitos para tomar a mídia como objeto de estudo e para construir uma leitura das mídias a partir da reflexão, da construção de conhecimento.
24. BARROS, Clóvis de. A publicidade como suporte pedagógico: a questão da discriminação por idade de Sukita. Famecos, Porto Alegre, n. 16, p. 122-135, dez. 2001. 


\section{comunicação \& educação • Ano XII • Número 2 • maio/ago 2007}

Se o fenômeno midiático é destaque em nossa época, cabe à escola estudá-lo, posto que compete a ela ser espaço privilegiado de reflexão e de múltiplas possibilidades de leitura do mundo.

Resumo: Atualmente, escola e mídia são experiências de todos: aprender as mídias no mais amplo sentido é uma competência fundamental para o exercício da cidadania. Este artigo apresenta uma discussão de caráter teórico - e não prescritivo - a respeito da utilização do texto publicitário como suporte pedagógico na construção de um sujeito crítico. Focamos nossa reflexão no Ensino Médio de escolas públicas, a etapa final da educação básica e último momento de formação geral, quando a maioria dos jovens brasileiros encerra a trajetória escolar.

Palavras-chave: texto publicitário, educação, suporte pedagógico, sujeito crítico.
Abstract: Nowadays, school and media experiences are shared by everyone: learning the media in a wider sense is a priority competence for the practice of citizenship. This article raises a theoretical discussion concerning the use of advertising text as pedagogical support to the construction of a critical individual. We focus our discussion on public High Schools, the final step of basic education and the last opportunity for general education for most young Brazilians.

Keywords: advertising text; education; pedagogical support; critical individual. 